7. Reprod. Fert. (1974) 36, 257-265

\title{
ISOLATION AND CHARACTERIZATION OF CADMIUM-BINDING PROTEIN FROM RAT TESTES
}

\author{
KARTAR SINGH, R. NATH AND R. N. CHAKRAVARTI \\ Department of Biochemistry and Experimental Medicine, \\ Postgraduate Institute of Medical Education and Research, \\ Chandigarh, India
}

(Received 4th December 1972)

\begin{abstract}
Summary. A cadmium-binding protein (Cd-BP) has been isolated and characterized using ${ }^{109} \mathrm{Cd}$ to elucidate the nature of the binding of cadmium to rat testis. The protein labelled with ${ }^{109} \mathrm{Cd}$ was isolated using Sephadex gel filtration with G-75 and G-25. The cadmium bound selectively in vivo to a low molecular weight protein and ${ }^{109} \mathrm{Cd}$ remained bound to the Cd-BP at $\mathrm{pH} 7 \cdot 0$, but dissociated from it at $\mathrm{pH} 2 \cdot 0$. The ultraviolet absorption spectra were characteristically different at the two $\mathrm{pH}$ values. The molecular weight of the protein was 15,000 as determined by Sephadex G-75 gel filtration. Disc-gel electrophoresis showed one major and two minor bands. All these observations suggest that rat testis Cd-BP, though similar in some respects, differs from Cd-BP of liver and kidney in absorption spectra, molecular weight and disc-gel electrophoresis.
\end{abstract}

\section{INTRODUCTION}

A single parenteral administration of cadmium has been shown to induce a rapid irreversible degeneration of the germinal epithelium of the testis resulting in permanent loss of fertility and associated with temporary damage to the interstitial tissues of the testis of most mammals including the rat (Pařizek, 1957, 1960; Kar, Das \& Mukerji, 1960; Gunn, Gould \& Anderson, 1963; Chiquoine, 1964). Gunn, Gould \& Anderson (1968) have suggested that the specific site where cadmium produces acute testicular injury is the vascular endothelium. Webb (1972) studied the biochemical effects of cadmium injury on mouse and rat testis with regard to the competitive antagonism between $\mathrm{Cd}^{2+}$ and $\mathrm{Zn}^{2+}$ and has shown that the antagonism occurs in the epididymis. A cadmium-binding protein (Cd-BP) has been shown to exist in various mammalian tissues, such as the liver and the kidney (Kagi \& Vallee, 1960, 1961 ; Pulido, Kagi \& Vallee, 1966; Shaikh \& Lucis, 1971a). The administra- 
tion of cadmium induces the synthesis of this protein (Piscator, 1964; Shaikh \& Lucis, 1970). It has been postulated that this protein in liver and kidney represents a biological system which protects the organs from the toxic effects of cadmium (Shaikh \& Lucis, 1971b).

Wisniewska-Knypl \& Jablonska (1970) have studied the binding of ${ }^{115} \mathrm{Cd}$ in rat liver and have shown that it binds selectively to metallothionein. Nordberg, Piscator \& Lind (1971) studied the distribution of cadmium among protein fractions of mouse liver and concluded that cadmium binds to high molecular weight proteins soon after injection whereas $24 \mathrm{hr}$ later it associates with a low molecular weight protein. Singh \& Nath (1972) reported the isolation and identification of Cd-BP from rat testis and showed that cadmium binds to a low molecular weight protein after $24 \mathrm{hr}$.

Though cadmium in very low dosage damages the testis, its mode of action remains unresolved. To elucidate the nature of the binding of cadmium to rat testis, a detailed study of the isolation and characterization of Cd-BP from this organ has been undertaken.

\section{MATERIALS AND METHODS}

Male albino rats weighing 200 to $225 \mathrm{~g}$, which were obtained from the central animal house of this Institute, were used for this study. The animals were maintained on standard diet and had free access to water. Animals were injected intraperitoneally with $20 \mu \mathrm{Ci}{ }^{109} \mathrm{Cd}$ (carrier-free, obtained from Radiochemical Centre, Amersham, England) and were killed after $24 \mathrm{hr}$. The scheme used to isolate Cd-BP from the testes is summarized in Text-fig. 1. The testes were removed and $25 \%(\mathrm{w} / \mathrm{v})$ homogenate was prepared in cold $0.25 \mathrm{M}$-sucrose, buffered with $0.01 \mathrm{M}$-tris- $\mathrm{HCl}$ at $\mathrm{pH} 7.4$. The homogenate $(4.5 \mathrm{ml})$, containing $7000 \mathrm{ct} / \mathrm{min}$, was centrifuged at $105,000 \mathrm{~g}$ in a VAC $60 \mathrm{Z}$ Ultracentrifuge. The supernatant thus obtained, containing high radioactivity $(6165 \mathrm{ct} / \mathrm{min} / 4 \mathrm{ml}$ ), was used for further studies. The pellet contained only $10 \%$ of the radioactivity and was discarded. The Cd-BP labelled with ${ }^{109} \mathrm{Cd}$ was isolated from the supernatant by the modified method of Pulido et al. (1966) and Shaikh \& Lucis (1971a). The supernatant $(4.0 \mathrm{ml})$, containing $75.0 \mathrm{mg}$ protein, was chromatographed on a Sephadex G-75 column $(56 \times 1.4 \mathrm{~cm})$ equilibrated with $0.01 \mathrm{M}$ tris-HCl buffer and proteins were eluted with the same buffer. The radioactivity and absorbance at 250 and $280 \mathrm{~nm}$ were determined. Fractions (17 to 23) from Sephadex G-75 gel filtration (Text-fig. 2), having a total volume of $17.5 \mathrm{ml}$, were pooled and concentrated in the cold. The concentrate was designated Fraction II and used for further study. All other fractions having low radioactivity $(<200 \mathrm{ct} / \mathrm{min} /$ fraction) were discarded.

The binding affinity of cadmium was determined as follows: Fraction II was divided into two equal parts. Each portion was chromatographed separately on Sephadex G-25 column $(45 \times 1.4 \mathrm{~cm})$. In the first experiment, the column was equilibrated with $0.001 \mathrm{M}$-tris- $\mathrm{HCl}$ buffer, $\mathrm{pH} 7 \cdot 0$, and proteins were eluted with the same buffer. The fractions numbering 12 to 14 were pooled and named Fraction IIIa (Text-fig. 3). The other portion of Fraction II was acidified to 
$\mathrm{pH} 2.0$ with $0.1 \mathrm{~N}-\mathrm{HCl}$ and chromatographed as above on Sephadex G-25. The protein was eluted with $0.01 \mathrm{~N}-\mathrm{HCl}$. The fractions numbering 12 to 14 were named Fraction IIIb (Text-fig. 4). The eluates from the above experiments were assayed for radioactivity and absorbance at 280 and $250 \mathrm{~nm}$. Fractions IIIa and IIIb were subjected to ultraviolet absorption spectra between 225 and $300 \mathrm{~nm}$.

The radioactivity of ${ }^{109} \mathrm{Cd}$ was assayed by a $\gamma$-ray medical spectrometer (Atomic Energy Establishment, Trombay, Bombay). The absorbance at 250 and $280 \mathrm{~nm}$ and absorption spectra (225 to $300 \mathrm{~nm}$ ) were measured with a Beckman ODU Spectrophotometer.

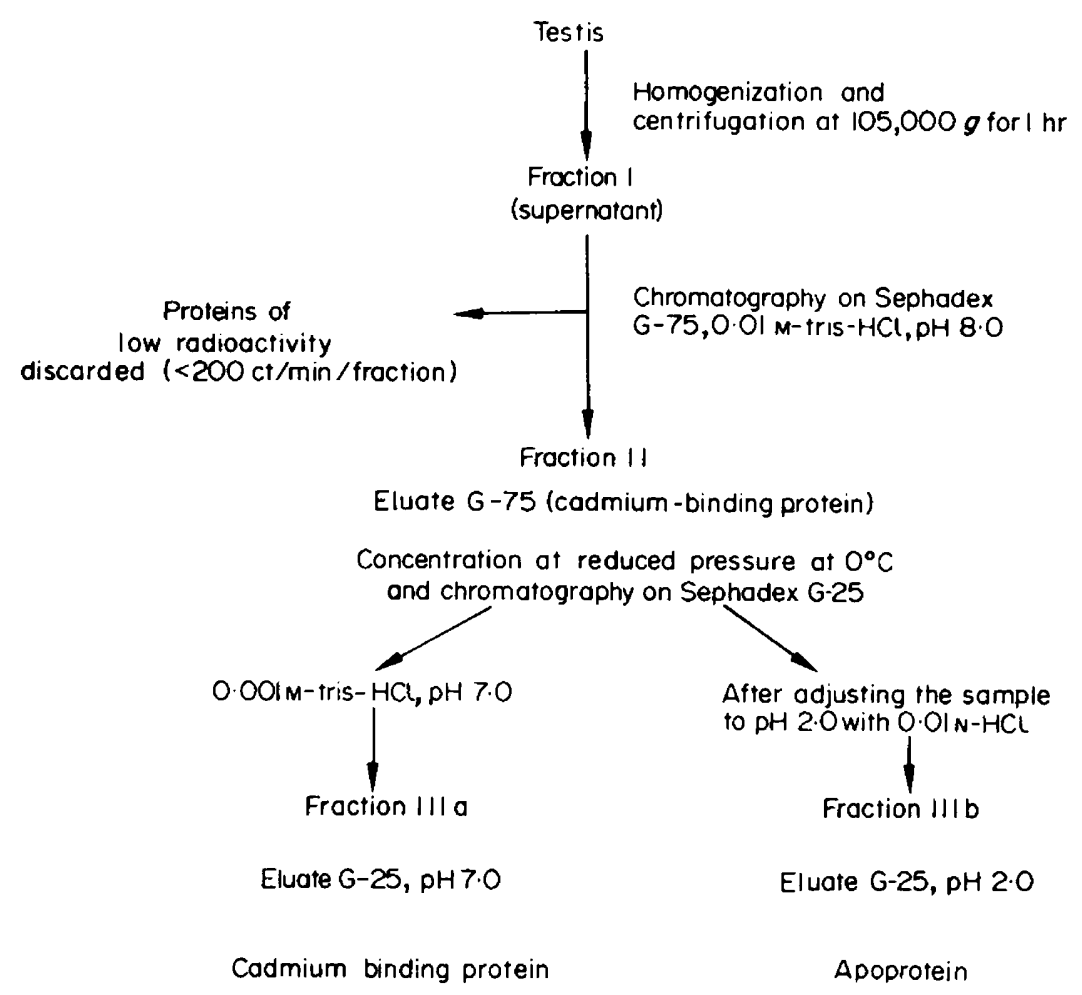

Text-Fig. 1. Scheme for the isolation of a cadmium-binding protein from rat testis.

The molecular weight of Cd-BP from rat testis isolated as above (Fraction IIIa) was determined according to the method of Andrews (1964), using a Sephadex gel filtration G-75 column $(56 \times 1.4 \mathrm{~cm})$ equilibrated with $0.01 \mathrm{M}$-tris$\mathrm{HCl}$ buffer, $\mathrm{pH} 8.0$, at $17^{\circ} \mathrm{C}$. A sample containing $4.0 \mathrm{mg}$ of protein in $2 \mathrm{ml}$ was applied to the column. The elution volume (V) of the Cd-BP was estimated by gamma counting of the ${ }^{109} \mathrm{Cd}$ tracer in a $2 \cdot 5-\mathrm{ml}$ fraction. The void volume $\left(\mathrm{V}_{0}\right)$ of the column was determined, using Blue dextran (mol. wt, $\left.2 \times 10^{6}\right)$. The calibration curve was prepared from the elution volumes of three conventional proteins of known molecular weight, i.e. cytochrome C (mol. wt, 12,270), 
Table 1. Uptake of ${ }^{109} \mathrm{Cd}$ in rat tissues

\begin{tabular}{l|c|c}
\hline \multirow{3}{*}{ Tissues } & \multicolumn{2}{|c}{$\%$ administered dose after $24 \mathrm{hr}$} \\
\cline { 2 - 3 } & Per g tissue & In total tissue \\
\hline Liver & $11 \cdot 76$ & $49 \cdot 39$ \\
Kidney & $4 \cdot 10$ & $4 \cdot 10$ \\
Testis & $0 \cdot 11$ & $0 \cdot 23$ \\
\hline
\end{tabular}

lysozyme (mol. wt, 17,500) and ovalbumin (mol. wt, 45,000). Lysozyme and ovalbumin were assayed spectrophotometrically at $280 \mathrm{~nm}$ and cytochrome $\mathrm{C}$ was measured at $410 \mathrm{~nm}$. The ratio $\mathrm{V} / \mathrm{V}_{0}$ of standard proteins versus the logarithms of their molecular weights gave a linear plot (Text-fig. 6) from which the molecular weight of Cd-BP was determined.

Disc-gel electrophoresis (Davis, 1964) was performed on Fraction IIIa. The polyacrylamide gel $(7 \%$ ) was prepared using tris-glycine buffer of $\mathrm{pH} \mathrm{8.9.}$ The current applied was $5 \mathrm{~mA} /$ column. The gel was stained with $1 \%$ amido schwartz in $7 \%$ acetic acid.

\section{RESULTS}

The uptake of ${ }^{109} \mathrm{Cd}$ in liver, testis and kidney is shown in Table 1. It is evident from the table that testis accounted for only $0.23 \%$ of the total counts injected.

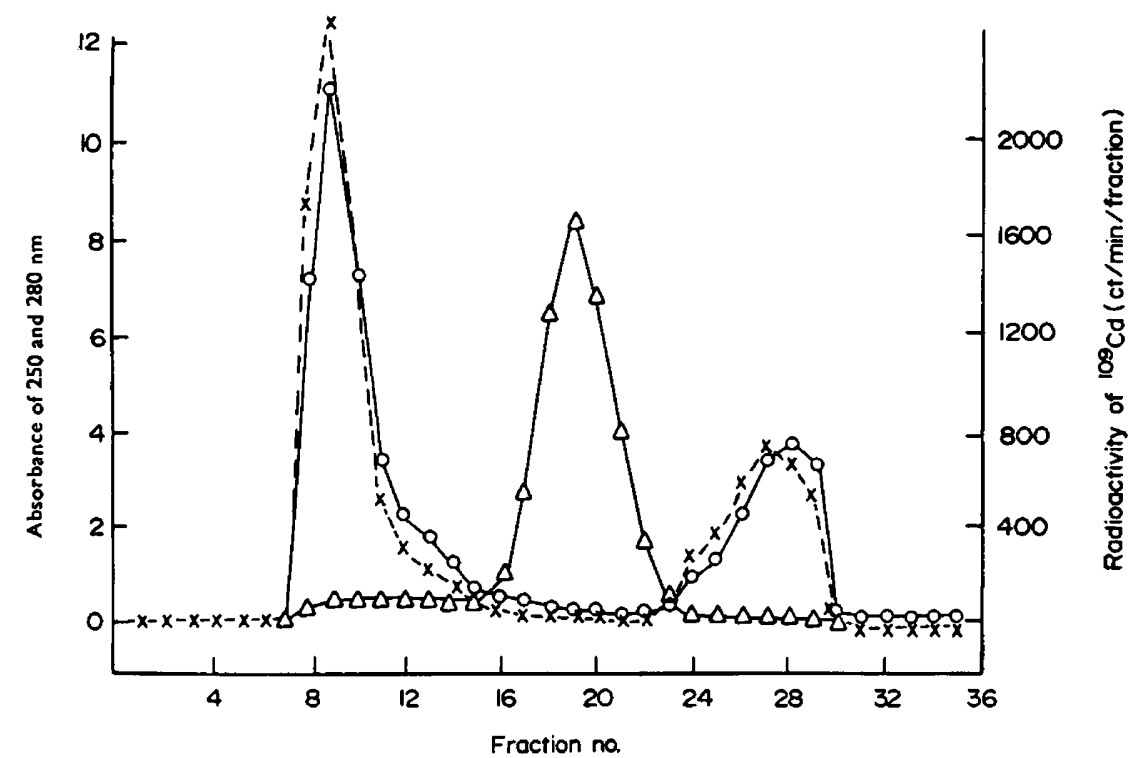

TEXT-FIG. 2. Binding in vivo of a single dose of ${ }^{109} \mathrm{Cd}$ to protein of rat testis. Sephadex gel G-75 column of $56 \times 1.4 \mathrm{~cm} ; 0.01 \mathrm{M}$-tris- $\mathrm{HCl}$ buffer, $\mathrm{pH} 8.0$; flow rate, $15 \mathrm{ml} / \mathrm{hr}$; temperature, $17^{\circ} \mathrm{C}$; fractions collected, $2.5 \mathrm{ml}$ each. 


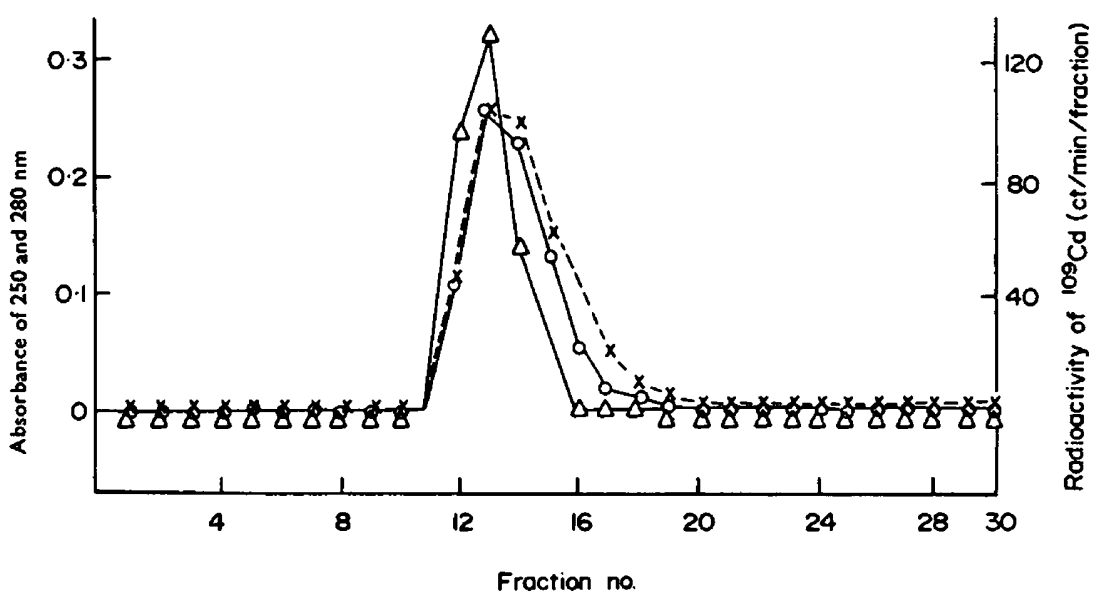

TexT-Fig. 3. Chromatography of cadmium-binding protein on Sephadex G-25 in neutral medium, $0.001 \mathrm{M}$-tris-HCl, $\mathrm{pH} 7 \cdot 0$.

The supernatant obtained after centrifugation contained $90 \%(6165 \mathrm{ct} / \mathrm{min} /$ $4.0 \mathrm{ml})$ and the pellet, $10 \%(700 \mathrm{ct} / \mathrm{min})$, of the radioactivity. The supernatant from rat testis homogenate was fractionated on Sephadex G-75 for the isolation of Cd-BP. The elution pattern (Text-fig. 2) demonstrates that ${ }^{109} \mathrm{Cd}$ binds selectively to a low molecular weight protein. The optical density at $280 \mathrm{~nm}$ in this region varied from $0 \cdot 112$ to $0 \cdot 415$. The supernatants of liver and kidney homogenates of these animals when chromatographed on Sephadex G-75 showed similar elution patterns to those obtained for testis (unpublished observation). The elution pattern of one portion of Fraction II chromatographed on Sephadex G-25 in neutral medium is shown in Text-fig. 3. The protein and radioactivity eluted in a single peak, which indicates that the tracer remains bound to the protein at $\mathrm{pH} 7 \cdot 0$. The other portion of the Fraction II was

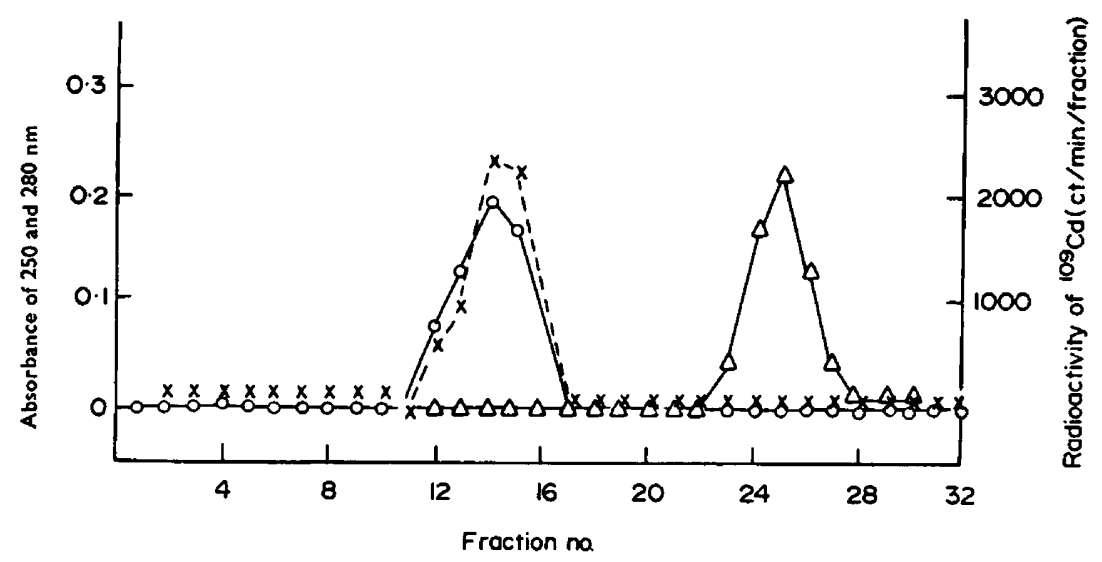

Text-Fig. 4. Chromatography of cadmium-binding protein on Sephadex G-25 in acidic medium adjused to $\mathrm{pH} 2 \cdot 0$ with $0.1 \mathrm{~N}-\mathrm{HCl}$. 


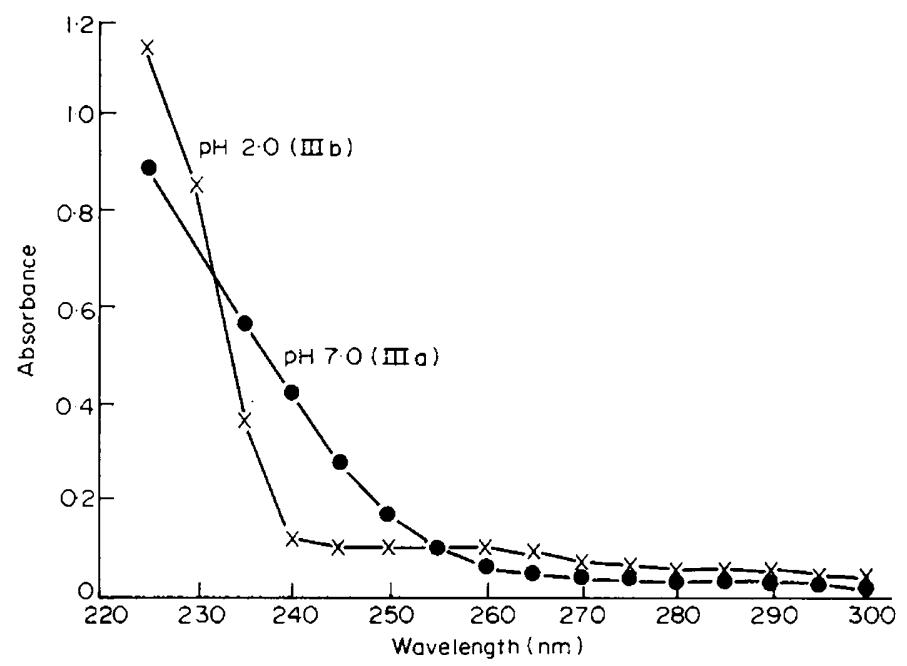

Text-Fig. 5. Absorption spectra of protein fractions IIIa and IIIb.

acidified to $\mathrm{pH} 2 \cdot 0$ and chromatographed on Sephadex G-25. Here, the protein and radioactivity eluted in different fractions. The elution pattern demonstrated that ${ }^{109} \mathrm{Cd}$ dissociated completely from the apoprotein at acidic $\mathrm{pH}$ (Text-fig. 4). No radioactivity could be detected in fractions having protein.

Absorption spectra of Cd-BP at $\mathrm{pH} 7.0$ and $\mathrm{pH} 2.0$ are shown in Text-fig. 5. The absorbance shoulder characteristic for the Cd-BP disappears after the dissociation of cadmium from the apoprotein in acidic medium.

As calculated from Text-fig. 6, the molecular weight of the Cd-BP from rat

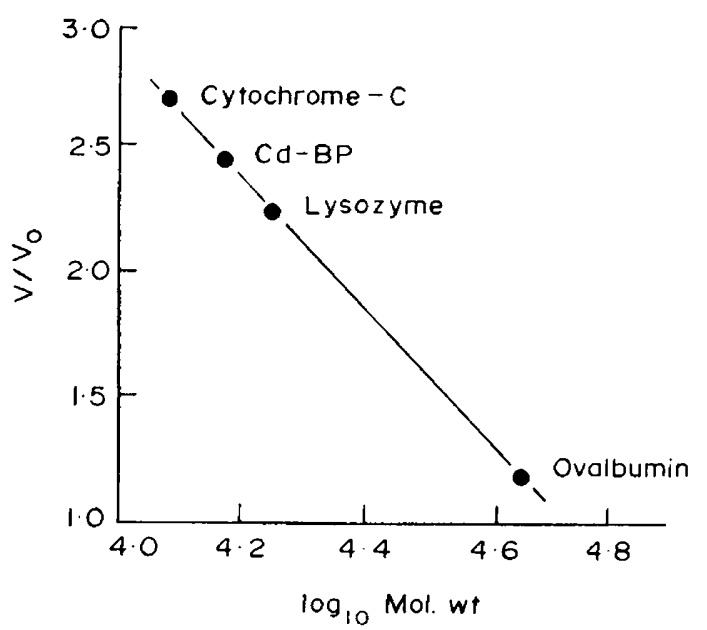

Text-FIG. 6. Determination of molecular weight of cadmium-binding protein (Cd-BP) from rat testis. $\mathrm{V}=$ elution volume, and $\mathrm{V}_{0}=$ void volume, of particular protein. Sephadex G-75 column of $56 \times 1.4 \mathrm{~cm} ; 0.01$ M-tris-HCl buffer, pH 8.0; flow rate, 15 $\mathrm{ml} / \mathrm{hr}$; temperature, $17^{\circ} \mathrm{C}$; fractions collected, $2.5 \mathrm{ml}$ each. 
PLATE 1

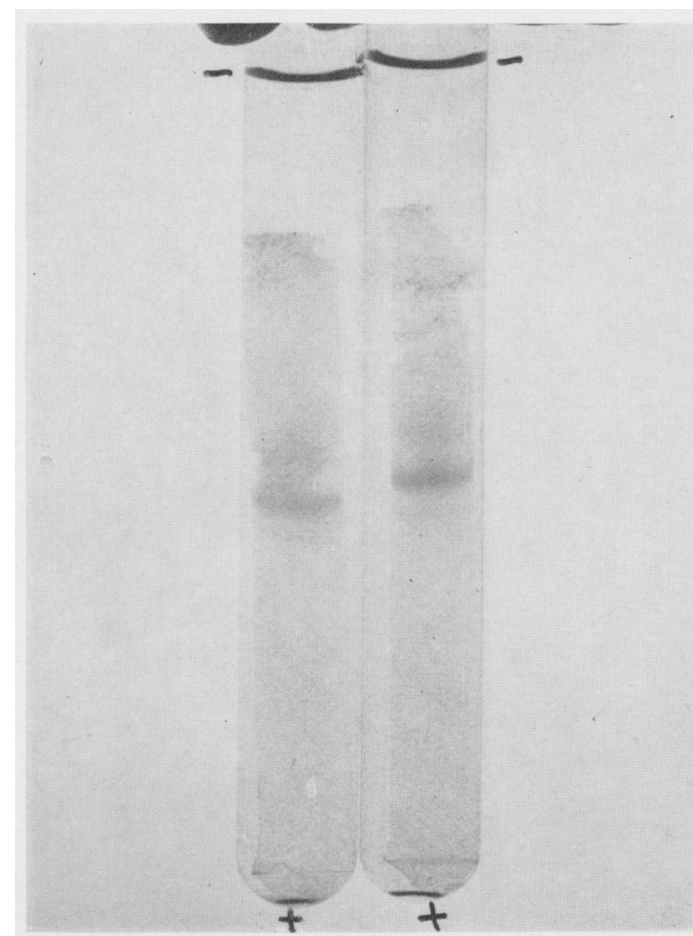

(a)

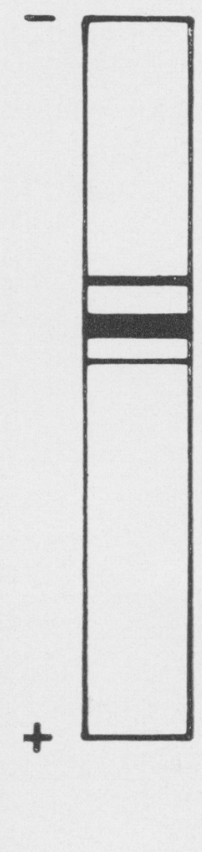

(b)

Disc-gel electrophoresis of cadmium-binding protein from rat testis, showing one major and two minor bands: (a) polyacrylamide gel stained with anido schwartz; (b) diagrammatic representation of bands seen in (a). 
testis was about 15,000 . This is higher than the kidney metallothionein which has a molecular weight around 11,000 (Pulido et al., 1966). The limit of accuracy of the method employed has been estimated to be about 10\% (Andrews, 1964). The disc-gel electrophoresis of Fraction IIIla showed one major and two minor bands (Pl. 1, Figs a and b).

\section{DISCUSSION}

Cadmium is known to bind selectively to the low molecular weight protein fraction (metallothionein) of the soluble cytoplasmic fraction of liver and kidney (Wisniewska-Knypl \& Jablonska, 1970; Shaikh \& Lucis, 1971a). The results of this study, taken with those of a previous study (Singh \& Nath, 1972), show that a Cd-BP of low molecular weight also exists in the rat testis. The protein is present in the soluble fraction of the testis as shown by the recovery of over $90 \%$ of total testis radioactivity in this fraction. It eluted as a single homogeneous peak on gel filtration on Sephadex G-75 at pH 8.0. Lowering the $\mathrm{pH}$ to 2.0 caused complete dissociation of the metal from the apoprotein as no radioactivity was detected in the protein peak when chromatographed at $\mathrm{pH} 2.0$ on Sephadex G-25. Liver and kidney homogenates from the same group of rats showed very similar properties when subjected to these procedures (unpublished observation).

The absorption spectra of this protein at $\mathrm{pH} 7.0$ showed high absorption at $225 \mathrm{~nm}$ which decreased to $1 / 3$ at $245 \mathrm{~nm}$. The ratio of absorbance at $250 \mathrm{~nm}$ to $280 \mathrm{~nm}$ was 4.0 . The ratio in the case of liver is 5.0 (Nordberg et al., 1971) and for kidney is 2.0 (Pulido et al., 1966). Exposure to low $\mathrm{pH}$ resulted in loss of absorption between 225 and $240 \mathrm{~nm}$ from $1 \cdot 14$ to $0 \cdot 13$, indicating that this loss of absorption was as a result of dissociation of cadmium from the Cd-BP. In the case of rat kidney protein, the corresponding loss in absorbance was only from $0 \cdot 18$ to 0.075 (Wisniewska, Trojanowska, Piotrowska \& Jakubowski, 1970), indicating that the nature and extent of binding of this metal is different for these tissues. Moreover, the absorption spectra of the apoprotein from kidney and testis are different, indicating that the nature of these proteins is characteristic of these organs.

Recently, Chen, Wagner, Ganther \& Hoekstra (1972) have reported the isolation of $\mathrm{Cd}-\mathrm{BP}$ from rat testis using ${ }^{109} \mathrm{Cd}$. They isolated the protein $30 \mathrm{~min}$ after the administration of ${ }^{109} \mathrm{Cd}(0.011 \mathrm{mmol} / \mathrm{kg})$. Their data on labelling pattern confirm the above results. They report that the absorbance of this protein is very low in the u.v. range. We have been able to measure the absorbance in the range from 225 to $300 \mathrm{~nm}$ (Text-fig. 5) for both the metalloprotein and the apoprotein. This difference may be due to the fact that in this experiment the cadmium was injected $24 \mathrm{hr}$ before the animals were killed. It has been shown by Nordberg et al. (1971) that cadmium will only bind to metallothionein in mouse liver $24 \mathrm{hr}$ after its administration. Before that, it is bound only to high molecular weight protein, which is different from the mode of binding of ${ }^{109} \mathrm{Cd}$ to testis (Chen et al., 1972). We have not carried out any experiments at this short interval. The molecular weight reported by Chen et al. (1972) is 10,000 for this protein. This is lower than the value reported here. The reason for this 
difference may be due to the method used for determination of the molecular weight by these authors (details of the method are not described by them).

The rôle of metallothionein present in liver and kidney as a trap for cadmium and serving as a protecting agent has been postulated (Shaikh \& Lucis, 1971b). Chen et al. (1972) have shown that Cd-BP from testis has some rôle to play in the testicular damage produced by cadmium. The present study shows that the $\mathrm{Cd}-\mathrm{BP}$ of rat testis, though similar in some respects, is quite different from the Cd-BP of liver and kidney in absorption spectra, molecular weight and disc-gel electrophoresis. It is possible that cadmium may be dissociating from the apoprotein at a much faster rate than in the case of the liver and kidney, thus producing tissue injury to the testis at a much lower concentration. Further work on the physicochemical properties of this protein is under study to clarify its physiological rôle.

\section{ACKNOWLEDGMENTS}

We wish to thank the W.H.O. for obtaining the ${ }^{109} \mathrm{Cd}$ from the Radiochemical Centre, Amersham, England, and Mr Vijay Lyall for his skilled assistance.

\section{REFERENCES}

ANDREws, P. (1964) Estimation of the molecular weights of proteins by Sephadex gel filtration. Biochem. 7. 91, 222.

Chen, R., Wagner, P., Ganther, H. E. \& Hoekstra, W. G. (1972) A low molecular weight cadmiumbinding protein in testis of rats. Possible role in cadmium induced testicular damage. Fedn Proc. Fedn Am. Socs exp. Biol. 31, 2725, Abstr.

Chiquorne, A. D. (1964) Observations on the early events of cadmium necrosis of the testis. Anat. Rec. $149,23$.

Davis, B. J. (1964) Disc electrophoresis. II. Methods and application to human serum protein. Ann. N.Y. Acad. Sci. 121, 404.

Gunn, S. A., Gould, T. G. \& Anderson, W. A. D. (1963) The selective injurious response of testicular and epididymal blood vessels to cadmium and its prevention by zinc. Am. J. Path. 42, 685 .

Gunn, S. A., Gould, T. C. \& ANDERson, W. A. D. (1968) Mechanism of zinc, cysteine and selenium protection against cadmium-induced vascular injury to mouse testis. 7 . Reprod. Fert. 15, 65.

KAGI, J. R. H. \& VALLEE, B. L. (1960) Metallothionein, a cadmium and zinc containing protein from equine renal cortex. 7. biol. Chem. 235, 3460.

KAGI, J. R. H. \& VALLEE, B. L. (1961) Metallothionein, a cadmium and zinc containing protein from equine renal cortex. II. Physicochemical properties. F. biol. Chem. 236, 2435.

Kar, A. B., Das, R. P. \& MukerJI, B. (1960) Prevention of cadmium induced changes in the gonads of rat by zinc and selenium-a study in antagonism between metals in the biological system. Proc. natn. Inst. Sci. India, B, 26, Suppl. 40.

Nordberg, G. F., Piscator, M. \& Lind, B. (1971) Distribution of cadmium among protein fractions of mouse liver. Acta pharmac. tox. 29, 456.

PAŘ́zík, J. (1957) The destructive effect of cadmium ion on testicular tissue and its prevention by zinc. 7. Endocr. 15, 56.

Paḱízek, J. (1960) Sterilization of the male by cadmium salts. J. Reprod. Fert. 1, 294.

Piscator, M. (1964) On cadmium in normal human kidneys together with a report on the isolation of metallothionein from livers of cadmium exposed rabbits. Nord. hyg. Tidskr. 45, 76.

Pulido, P., Kagi, J. R. H. \& Vallee, B. L. (1966) Isolation and some properties of human metallothionein. Biochemistry, 5, 1768.

Shaikh, Z. A. \& Lucis, O. J. (1970) Induction of cadmium binding protein. Fedn Proc. Fedn Am. Socs exp. Biol. 29, 301, Abstr.

Shatkн, Z. A. \& Lucis, O. J. (1971a) Isolation of cadmium binding proteins from rat liver. Experientia, $27,1024$.

Shaikh, Z. A. \& Lucis, O. J. (1971b) The nature and biosynthesis of cadmium binding proteins. Fedn Proc. Fedn Am. Socs exp. Biol. 30, 238, Abstr. 
SiNGH, K. \& NATH, R. (1972) Studies on the identification of cadmium binding protein from rat testes. Biochem. 7. 128, 48P.

WeBs, M. (1972) Biochemical effects of $\mathrm{Cd}^{2+}$ injury in the rat and mouse testis. $\mathcal{F}$. Reprod. Fert. 30, 83. WisNiewsKa-KNYPL, J. M. \& JABLONSKA, J. (1970) Selective binding of cadmium in vivo on metallothionein in rat's liver. Bull. Acad. pol. Sci. Cl. II Ser. Sci. biol. 18, 321.

Wisniewska, J. H., Trojanowska, B., Piotrowski, J. \& Jakubowski, M. (1970) Binding of mercury in the rat kidney by metallothionein. Toxic. appl. Pharmac. 16, 754. 